\title{
A Paraguayan Case Study on the Production of Electricity from Fuel Cells for Distributed Generation
}

\author{
Michel Osvaldo Galeano Espínola \\ Department of Chemical Engineering, National University of Asuncion (UNA), San Lorenzo, Paraguay
}

Email address:

michelosvaldo@qui.una.py

\section{To cite this article:}

Michel Osvaldo Galeano Espínola. A Paraguayan Case Study on the Production of Electricity from Fuel Cells for Distributed Generation. International Journal of Energy and Power Engineering. Special Issue: Energy Conversion and Management. Vol. 3, No. 6-3, 2014 , pp. 8-12. doi: $10.11648 /$ j.ijepe.s.2014030603.12

\begin{abstract}
The result of a preliminary economic evaluation of distributed generation of electricity with a molten carbonate fuel cell (MCFC) in Paraguay is presented in this work. For this purpose, a mathematical model that represents the main technical and economic characteristics involved in the operation of MCFCs was applied. The model is applied in a horizon of 20 years and shows how costs are influenced by the projected energy demand increase of the studied population and by the decrease of MCFC unit cost due to technological advances and mass production. The studied population is Bahía Negra district in the department of Alto Paraguay. The results show that the generation cost of electricity by MCFC is high, US\$ 290/MWh and US\$ 270/MWh, for conservative and optimistic scenarios, respectively. However, in these situations, the feasibility analysis of electricity supply to isolated communities with low living standards and in developing countries based only on the comparison and quantification in monetary terms is not enough. This is because there are intangible benefits that are difficult to quantify and, therefore, to express in monetary terms. For example, it is very difficult to quantify in monetary terms the improvements in environmental conditions and quality of life of the community. Finally, the use of fuel cells for distributed generation of electricity in rural areas of Paraguay is feasible if the social and environmental aspects are considered, not just economics.
\end{abstract}

Keywords: Distributed Generation, Fuel Cells, Economics, Paraguay

\section{Introduction}

The End Use stage is crucial in the structure of any H2-based energy system and serves to harness its energy in the different sectors of society to satisfy the energy demand, and therefore its full development will determine the successful penetration and massive use of $\mathrm{H}_{2}$ as an energy vector in the immediate future [1]. This explains the interest of researchers from universities, research centers, energy companies and multinational agencies around the world, in developing services technologies related with the different ways of harnessing the energy contained in hydrogen that are economically viable [2]. Of all the energy technologies proposed, fuel cells are regarded as one of the most competitive and promising, with several potential applications throughout all sectors of society, in particular in automotive transport and the distributed generation of electricity from renewable energy sources for residential use, both in urban areas and in remote or isolated places [3,4]. In this respect, it is in the rural and remote regions of the developing countries, like Paraguay, that lack permanent and reliable energy services, where renewable and hybrid energy systems that include fuel cells as final conversion technologies are being used increasingly more frequently, raising the quality of life of these remote communities and contributing to their sustainable development [5].

An important part of the isolated communities of Paraguay is located in the department of Alto Paraguay, and the use of alternative local energy sources is presented as a rational way of using own natural resources. Besides improving the distortion associated with the distribution of goods and services in the region, this initiative will also bring these communities other direct and basic benefits as potable water, food preservation, resulting in improved food and nutrition security, improvement of health status (storage medicines and vaccines), public communication and especially citizenship. Within this overall context, there is the case of the Bahía Negra district in the department of Alto Paraguay. The population of Bahia Negra is approximately 5000 inhabitants. 


\section{Methodology}

\subsection{Selecting the Type of Fuel Cell}

According to [6], the feasibility of power generation technology is determined not only by its efficiency, but also by a wide range of factors which are important fuel prices, investment in plant and intensity of use of the plant. Typically, efficiency becomes more important the more expensive fuel and many hours of energy are needed throughout the year. Different types of fuel cells to have a varied level of technological development. Research programs on fuel cells are directed to the design of cells that produce results in operating conditions corresponding to a real application [7].

\subsection{Economic Assessment}

The variable commonly used to economically evaluate the operation of a fuel cell to the cost of electricity generation, which is calculated by the method of the cycle of life and annuity [8]. In this context, the proposed model calculates the total annual cost of electricity generation as well as the sum of fuel costs, investment and operation with respect to electricity produced by the fuel cell system to the same period. The cost of operation and maintenance is considered as a fraction of the cost of annualized investment. Finally, the annual electricity production depends directly on the energy demand of the studied community.

\subsubsection{Fuel Costs}

Depending of the type of fuel cell, fuel can be hydrogen, natural gas, biogas, etc. Annual fuel cost is obtained from (1):

$$
\mathrm{C}_{\mathrm{HA}}=\mathrm{C}_{\mathrm{HR}} \times \mathrm{C}_{\mathrm{H}}
$$

where $C_{H R}$ is the annual demand of fuel $\left(\mathrm{m}^{3} /\right.$ year) and $C_{H}$ is the fuel price $\left(\mathrm{US} \$ / \mathrm{m}^{3}\right)$. According to [10], the Heating Value of natural gas is $41,23 \mathrm{MJ} / \mathrm{m}^{3}$. Thus, (2) allows calculating the annual demand of natural gas:

$$
\mathrm{C}_{\mathrm{HR}}=\left(\mathrm{C}_{\mathrm{F}} \times \mathrm{D}_{\mathrm{FC}}\right) / \mathrm{P}_{\mathrm{F}}
$$

where $C_{F}$ is the fuel demand of the fuel cell system $(\mathrm{MJ} / \mathrm{h})$, $\mathrm{D}_{\mathrm{FC}}$ is the annual availability of the power plant (h/year) and $\mathrm{P}_{\mathrm{F}}$ is the heating value of natural gas $\left(\mathrm{MJ} / \mathrm{m}^{3}\right)$.

\subsubsection{Investment Costs}

According to [11] and [12], in order to evaluate the effect of the investment costs, they must be divided into fixed costs and variable costs, according to their dependence on the cell stack size. The fixed costs, which are referred to as equipment costs, do not change with the number of cells and are the costs of the reactant and product inlet and outlet devices and of the measuring and control elements; in addition to the costs of assembling the stack, and installing and coupling the system. The variable costs, which are referred to as cell costs, $\mathrm{C}_{\mathrm{C}}$, depend on their unit value and their number, in accordance with (3):

$$
\mathrm{C}_{\mathrm{C}}=\mathrm{C}_{\mathrm{UC}} \times \mathrm{N}_{\mathrm{C}}
$$

where $\mathrm{C}_{\mathrm{C}}$ is the fuel cell cost (US\$), $\mathrm{C}_{\mathrm{UC}}$ is the unit cost of the cells (US\$) and $\mathrm{N}_{\mathrm{C}}$ is the number of cells. Besides, the investments costs must to include the signal converter/adjuster, which depend of the power output [13], according to (4):

$$
\mathrm{C}_{\mathrm{CV}}=\mathrm{C}_{\mathrm{UCV}} \times \mathrm{P}_{\mathrm{OA}}
$$

where $\mathrm{C}_{\mathrm{CV}}$ is the signal converter/adjuster cost (US\$), $\mathrm{C}_{\mathrm{UCV}}$ is the unit cost of the signal converter/adjuster (US\$ $/ \mathrm{kW}$ ) and $\mathrm{P}_{\mathrm{OA}}$ is the AC power output $(\mathrm{kW})$. Thus, the mathematical expression for the investment cost is:

$$
\mathrm{C}_{\mathrm{INV}}=\mathrm{C}_{\mathrm{EQ}}+\mathrm{C}_{\mathrm{C}}+\mathrm{C}_{\mathrm{CV}}
$$

where $\mathrm{C}_{\mathrm{INV}}$ is the investment cost (US\$) and $\mathrm{C}_{\mathrm{EQ}}$ is the equipment $\operatorname{cost}^{1}$ (US\$).

To determine the annual investment cost, it is necessary to apply (6) to calculate the capital recovery factor [11]:

$$
\mathrm{F}=\left[\mathrm{d}(1+\mathrm{d})^{\mathrm{n}}\right] /\left[(1+\mathrm{d})^{\mathrm{n}}-1\right]
$$

where $\mathrm{F}$ is the capital recovery factor, $\mathrm{d}$ is the annual discount rate and $\mathrm{n}$ is the payment period (years). The equipment useful life is estimated in 20 years and cells useful life is 5 years (40.000 hours). Thus, the annualized costs are:

$$
\mathrm{C}_{\mathrm{EQA}}=\mathrm{F}_{\mathrm{EQ}} \times \mathrm{C}_{\mathrm{EQ}}
$$

and,

$$
\mathrm{C}_{\mathrm{CA}}=\mathrm{F}_{\mathrm{C}} \times \mathrm{C}_{\mathrm{C}}
$$

where $\mathrm{C}_{\mathrm{EQA}}$ is the annualized equipment cost (US\$/year), $\mathrm{F}_{\mathrm{EQ}}$ is the capital recovery factor for the equipment, $\mathrm{C}_{\mathrm{CA}}$ is the annualized cost of the cells (US\$/year) and $F_{C}$ is the capital recovery factor for the cells. In the case of the signal converter/adjuster, it was considered a useful life similar to the equipment (20 years):

$$
\mathrm{C}_{\mathrm{CVA}}=\mathrm{F}_{\mathrm{EQ}} \times \mathrm{C}_{\mathrm{CV}}
$$

where $\mathrm{C}_{\mathrm{CVA}}$ is the annualized cost of the signal converter/adjuster (US\$/year).

Thus, the annual investment is expressed by (10):

$$
\mathrm{C}_{\mathrm{IA}}=\mathrm{C}_{\mathrm{EQA}}+\mathrm{C}_{\mathrm{CA}}+\mathrm{C}_{\mathrm{CVA}}
$$

where $\mathrm{C}_{\mathrm{IA}}$ is the annual investment cost (US\$/year).

\subsubsection{Operation and Maintenance Costs (O\&M)}

Operation and maintenance costs had been considered as a percentage of annualized investment costs and equal to $6 \%$ [9]. Thus, the expression is given by (11):

$$
\mathrm{C}_{\mathrm{OMA}}=0,06 \times \mathrm{C}_{\mathrm{IA}}
$$

where $\mathrm{C}_{\mathrm{OMA}}$ is the operation and maintenance annualized cost (US\$/year).

Finally, (12) allows calculating electricity generation cost according to the annual quantity of electricity generated by the fuel cell system:

1 Referred to internal fuel reforming technology [9]. 


$$
\mathrm{C}_{\mathrm{E}}=\left(\mathrm{C}_{\mathrm{HA}}+\mathrm{C}_{\mathrm{IA}}+\mathrm{C}_{\mathrm{OMA}}\right) / \mathrm{E}_{\mathrm{EA}}
$$

where $C_{E}$ is the electricity generated cost (US\$ $/ \mathrm{kWh}$ ) and $E_{E A}$ is the annual quantity of electricity generated by the fuel cell system $(\mathrm{kWh} /$ year $)$.

This work spans a 20-year time horizon, taking into account the following: (a) 2013 was chosen as year one of the study (base year); (b) The base value of the equipment costs and of the cell unit costs are assumed to equal US\$ 1.440.000 and US\$ 1.110.000, respectively [9]; (c) The equipment costs must increase year on year as a result of the expected increase in the annual consumption of energy in Bahia Negra district. This increase in the costs is assumed to be $5 \%$ a year [14]; (d) The unit cost of the cells is expected to decrease in time due to technological improvements and to their mass production. In order to study this decrease, different scenarios have been assumed, and her two are considered: the first, more conservative scenario, establishes a linear decrease of $2 \%$ a year in the unit cost of the cells $\mathrm{C}_{\mathrm{UC}}$ [11]; the second, more optimistic scenario, assumes a larger decrease with a nonlinear power-type representation [15]:

$$
\mathrm{C}_{\mathrm{UC}}=\mathrm{C}_{\mathrm{UCO}} \times \mathrm{b}^{\Gamma(\mathrm{t}-\mathrm{to})}
$$

where $\mathrm{C}_{\mathrm{UC}}$ is the fuel cell unit cost (US\$/kW), $\mathrm{C}_{\mathrm{UCO}}$ is the fuel cell base cost for the year 2013 (US\$), b is the unit cost adjustment factor, $\Gamma$ is an exponential parameter, $t_{0}$ is the base year (2013) and the following years.

\section{Results}

\subsection{Selecting the Type of Fuel Cell}

The technology adopted in this work for distributed power generation is the DFC $\AA 300^{\mathrm{TM}}$ stationary fuel cell power plant from Fuel Cell Energy [16]. Its technical specifications are found in Appendix. The electrolyte in an MCFC is an alkali carbonate (sodium, potassium, or lithium salts, i.e., $\mathrm{Na}_{2} \mathrm{CO}_{3}$, $\mathrm{K}_{2} \mathrm{CO}_{2}$, or $\mathrm{Li}_{2} \mathrm{CO}_{3}$ ) or a combination of alkali carbonates that is retained in a ceramic matrix of lithium aluminum oxide $\left.(\mathrm{LiAlO})_{2}\right)$ A MCFC operates at $600^{\circ} \mathrm{C}$ to $700^{\circ} \mathrm{C}$ where the alkali carbonates form a highly conductive molten salt with carbonate ions $\left(\mathrm{CO}_{3}{ }^{\circ}\right)$ providing ionic conduction through the electrolyte matrix. Relatively inexpensive nickel (Ni) and nickel oxide $(\mathrm{NiO})$ are adequate to promote reaction on the anode and cathode respectively at the high operating temperatures of an MCFC. MCFCs offer greater fuel flexibility and higher fuel-to-electricity efficiencies than lower temperature fuel cells, approaching $60 \%$. The higher operating temperatures of MCFCs make them candidates for combined-cycle applications, in which the exhaust heat is used to generate additional electricity. When the waste heat is used for co-generation, total thermal efficiencies can approach $85 \%$ [17]. Fig. 1 shows a $300 \mathrm{~kW}_{\mathrm{e}}$ DFC fuel cell power plant [16].

FuelCell Energy's DFC300 system is a self-contained electrical power generation system capable of providing 300 $\mathrm{kW}$ of high-quality baseload power, with $47 \%$ electrical efficiency, 24 hours a day, 7 days a week. Featuring ultra-low emissions, low operating noise, and a small footprint, the DFC300 is suitable for locations where traditional power generation technologies are not feasible or desirable. The DFC300 can be used for on-site power generation and can be integrated with multiple plants to provide $600 \mathrm{~kW}$ or $900 \mathrm{~kW}$ of ultra-clean distributed generation [16].

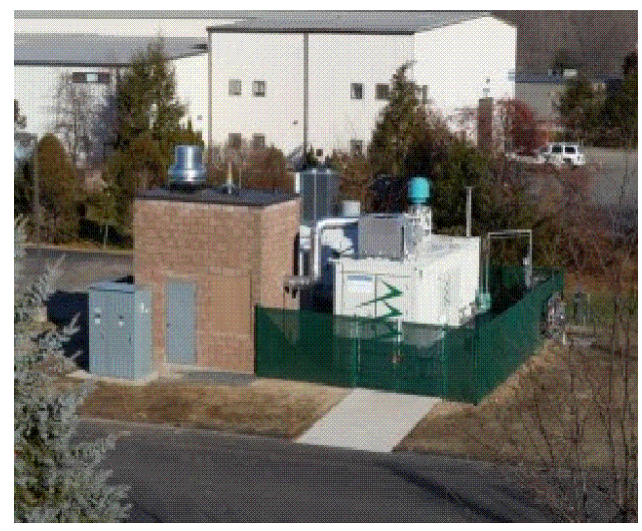

Figure 1. $300 \mathrm{~kW}$ DFC fuel cell power plant.

\subsection{Economic Assessment}

According to [18], the fuel used in this study is compressed natural gas from Pozo Independencia I of Gabino Mendoza town, Chaco. The price of compressed natural gas in Bahia Negra district is Gs. $3.750 / \mathrm{m}^{3}\left(85 \not / \mathrm{m}^{3}\right) 2$.

According to [19], the DFC 300 power plant cost, including installation, is about US\$ 1,7 million (US\$ 5.500/kW). The current installed cost for a DFC 300 unit averages about US\$7.000/kW, broken down as approximately US\$3.300/kW for the fuel cell module, US\$ $3.000 / \mathrm{kW}$ for the balance-of-plant (BOP), and US\$ $700 / \mathrm{kW}$ for conditioning, installation, and commissioning. It is misleading to compare this breakdown to similar breakdowns for other technologies because, unlike PEM and PAFC units, the DFC line of products incorporates the steam-methane reformer into the fuel cell stack module rather than the BOP making the stack module appear overly expensive. BOP costs include the gas cleanup system, a small pre-reformer, the process control system, all heat exchangers and water management systems, and the power conditioning section. The value of the various parameters is given in table 1 in order to apply the mathematical model to Bahia Negra district.

Table 1. Model parameters values

\begin{tabular}{llll}
\hline Parameters & Value & Unit & Source \\
\hline Natural gas cost & 85 & $\varnothing / \mathrm{m}^{3}$ & {$[18]$} \\
Annual discount rate & $10 \%$ & & {$[20]$} \\
Useful life of the equipment & 20 & years & {$[16]$} \\
Useful life of MCFC & 10 & years & {$[16]$} \\
Heating value of natural gas & 41,23 & $\mathrm{MJ} / \mathrm{m}^{3}$ & {$[10]$} \\
Energy demand of Bahia Negra district & 200 & $\mathrm{~kW}$ & {$[14]$} \\
Annual growth of energy demand & $5 \%$ & & {$[14]$} \\
\hline
\end{tabular}

21,00 US\$ = Gs. 4.418 (http.www.bcp.gov.py, accessed in june $\left.3^{\text {rd }}, 2014\right)$. 
The values obtained for the cost of electricity for both scenarios can be considered high compared with those calculated in other studies of distributed power for isolated communities from a fuel cell [21, 22, 20, 23]. However, in situations such as the one studied here, the supply of electricity to isolated communities with low living standards and in developing countries, the usual to assess the feasibility of an energy proposal based solely on the comparison and quantification in monetary terms of procedure costs and benefits is not the most appropriate. This is because there intangible benefits that are difficult to quantify and, therefore, expression in monetary terms. By the way, how can be quantified in monetary terms the improvements in environmental conditions and quality of life of the community. How to include a cost-benefit equation welfare of a rural family that has electricity and heat for lighting, refrigeration and cooking. Therefore, these results should be analyzed with broader criteria considering the purpose of the study. A possible alternative would be to extend the grid to Bahía Negra district. In that case, should consider the costs involved and the environmental impact. As [24] and [5], the cost of power transmission is US\$ $10.000 / \mathrm{km}$. To this cost must be added the cost of maintaining the complete transmission system. You should also consider the environmental impact of transmission lines and other distribution facilities covering an area of approximately $800 \mathrm{~km}^{2}$ [20]. Therefore, this alternative presents several obstacles. Finally, the use of fuel cells for distributed power in rural areas of Paraguay generation is in principle also feasible if the aspects of human and social development and environmental impacts are taken into account, not only the economic aspects.

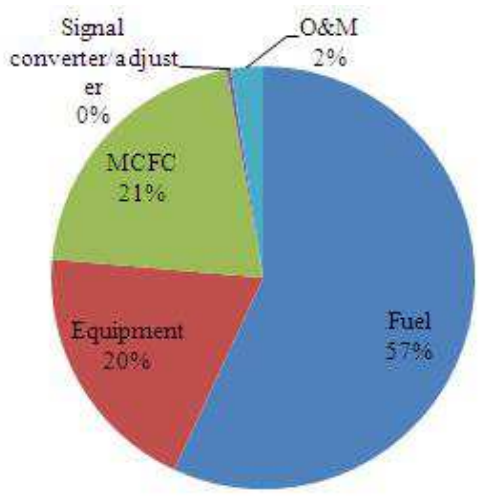

Figure 2. Distribution of component costs in the total cost of generating electricity from a $300 \mathrm{~kW}$ DFC fuel cell power plant.

The MCFC operates at high temperature, therefore, offers the possibility of cogeneration, i.e., the use of waste heat generated by the cell. According to [25], the advantage of the use of waste heat can be quantified in monetary terms by approximately US\$13/GJ. Consequently, it would represent a significant reduction in the cost of power generation. Fig. 2 shows the distribution of component costs in the total cost of generating electricity from a $300 \mathrm{~kW}_{\mathrm{e}}$ DFC fuel cell power plant. Fig. 2 shows that the fuel cost (compressed natural gas) is the most significant component in total electricity generation cost. Equipment cost is in second place, which has economies of scale. Nevertheless, MCFC costs are expected to decrease in the coming years due to advances in technology and mass production of these devices. Operation and maintenance costs represent only $2 \%$, a very low value compared with traditional technologies (gas turbines, steam turbines, reciprocating engines, Stirling engines), which have mechanical parts, unlike fuel cells that have no moving parts [6].

\section{Conclusion}

The results show that for both scenarios electricity cost generated by the $300 \mathrm{~kW}$ DFC power plant decreases asymptotically for the same year because the equipment cost and the MCFC cost offset one another, and interanually, due to the economy of scale effects. The decrease in electricity generation cost is sharper for the optimistic scenario. The tangible and intangible beneficial effects of the use of fuel cells, which can be summarized as a major improvement in the quality of life of the rural population in Bahía Negra district, mean the use of fuel cells is, in principle, viable as a final use technology for supplying the required energy to the rural sector of Paraguay. Fuel cells are an interesting option to satisfy the energy demand in remote communities or where it is not possible to extend electric power grid. Fuel cells are an alternative to noisy and polluting generators in remote regions. Energy liberalization and the promotion of renewable sources of energy can stimulate the use of fuel cells in the industry for stationary applications. The best market niches are commercial/collective power generation with power outputs from $200 \mathrm{~kW}$ to several MW, and domestic production, with power from $2 \mathrm{~kW}$ and $7 \mathrm{~kW}$. According to [26], the potential energy use of wastewater for biogas production in Paraguayan meat industry is estimated at $100 \mathrm{TJ}$ to $200 \mathrm{TJ}$ per year for a total amount of 40 to 60 fridges in Paraguay. This biogas can be used as fuel for MCFC power plants so that they can obtain electricity and heat avoiding using electricity from grid and high investments in boilers to obtain steam.

\section{Acknowledgements}

The author gratefully acknowledges the Faculty of Chemical Sciences of the National University of Asuncion.

\section{References}

[1] The hydrogen economy: opportunities, costs, barriers and R\&D needs. Washington, DC: The National Academies Press; 2004. $<$ http://www.nap.edu/ catalog/10922.html>.

[2] Solomon B, Banerjee A. A global survey of hydrogen energy research development and policy. Energy Policy 2006;34:781-92.

[3] Varigonda S, Kamatb M. Control of stationary and transportation fuel cell systems: progress and opportunities. Comput Chem Eng 2006;30:1735-48. 
[4] Agbossou K, Chahine R, Hamelin J, Laurencelle F, Anouar A, St.-Arnaud JM, et al. Renewable energy systems based on hydrogen for remote applications. J Power Sources 2001; 96: $168-72$.

[5] Bauen A, Hart A, Chase A. Fuel cells for distributed generation in developing countries - an analysis. Int J Hydrogen Energy 2003;28: 695-701.

[6] Nogueira, LAH; Lora, EES. Dendroenergia: Fundamentos e Aplicações. $2^{\circ}$ edição. Editora Interciência. Rio de Janeiro, Brasil. 2003. 199 páginas.

[7] Castells, XE. Tratamiento y valorización energética de residuos. Ediciones Díaz de Santos. Fundación Universitaria Iberoamericana. 2005. 1228 páginas.

[8] Frangopoulos, C; Nakos, L. Development of a model for thermoeconomic design and operation optimization of a PEM fuel cell system. Energy 2006; 31: 1501-19.

[9] http//:www.bloomenergy.com, accessed in March 2014.

[10] Jannuzzi, GM; Swisher, JNR. Planejamento integrado de recursos energéticos: meio ambiente, conservação de energia e fontes renováveis. Campinas, SP: Autores Associados, 1997. 246 páginas.

[11] Kazinm A. Economical and environmental assessments of proton exchange membrane fuel cells in public buildings. Energy Conversion Management, 2001; 42:763-72.

[12] Nelson, DB; Nehrir, MH; Wang, C. Unit sizing and cost analysis of stand-alone hybrid wind/PV/fuel cell power generation systems. Renewable Energy, 2006; 31:1641-56.

[13] Khan, MJ; Iqbal, MT. Pre-feasibility study of stand-alone hybrid energy systems for applications in Newfoundland. Renewable Energy, 2005; 30:835-54.

[14] Alfaro, IAF; Berra, ARP. Estudio de la factibilidad para la implementación de generación de la energía solar fotovoltaica en la localidad de Bahía Negra. Tesis de grado. Ingeniería Electromecánica. FIUNA. 2013.

[15] Smith R, Weeda M, de Groot A. Hydrogen infrastructure development in The Netherlands. Int J Hydrogen Energy 2007;32:1387-95.

[16] http://www.fuelcellenergy.com, accessed in July 2014.
[17] http://www.ballard.com/cogeneration fuelcells/Case studies.h tm, accessed in July 2014.

[18] Álvarez, A. División de Generación Hidroeléctrica. Gerencia Técnica. Administración Nacional de Electricidad. Comunicación informal realizada el 24 de marzo de 2014 y el 3 de junio del mismo año.

[19] Remick, R; Wheeler, D. Molten Carbonate and Phosphoric Acid Stationary Fuel Cells: Overview and Gap Analysis. Technical Report NREL/TP-560-49072. September 2010.

[20] Contreras, A; Posso, F; Guervos, E. Modelling and simulation of the utilization of a PEM fuel cell in the rural sector of Venezuela. Applied Energy (2009), doi: 10.1016/j.apernergy. 2009.05.040

[21] Santarelli, M; Cali, M; Macagno, S. Design and analysis of stand-alone hydrogen energy systems with different renewable sources. International Journal of Hydrogen Energy, 2004; 29:1571-86.

[22] Santarelli, M; Pellegrino, D. Mathematical optimization of a RES-H2 plant using a black box algorithm. Renewable Energy, 2005; 30:493-510.

[23] Furlan, AL. Análise técnica e econômica do uso do hidrogênio como meio armazenador de energia elétrica proveniente de fontes eólicas. Tese de Doutorado. Faculdade de Engenharia Mecânica. Universidade Estadual de Campinas, SP, Brasil. 2012. 86 páginas.

[24] Isherwood, W; Smith, J; Aceves, S; Berry, G; Clark, W; Johnson, $\mathrm{R}$ et al. Remote power systems with advanced storage technologies for Alaskan villages. Energy, 2000; 25:1005-20.

[25] Gosnell, J. Efficient Ammonia Production. KBR Energy and Chemicals. Presentation in the Hydrogen Conference organized by National Argonne Laboratory. 13 October 2005.

[26] VMME y GIZ. Evaluación de potenciales de energía renovable en Paraguay, estudio de cuatro casos. Publicación elaborada en el marco de un proyecto del Ministerio de Obras Públicas y Comunicaciones (MOPC) a través del Viceministerio de Minas y Energía (VMME), con la cooperación de la Cooperación Alemana al Desarrollo (GIZ). Noviembre de 2013. 23 páginas. Disponible en http//:www.ssme.gov.py. 